Антоніна Марковська

кандидат філологічних наук, дочент кафедри іноземних мов Миколаївський національний аграрний університет, orcid.org/0000-0003-1598-7517

М. Миколаїв, Украӥна +38(066)4907450, markovska@mпаи.edu.иа

ольга Саламатіна кандидат філологічних наук, дочент кафедри іноземних мов Миколаївський національний аграрний університет, orcid.org/0000-0002-1457-2822

М. Миколаїв, Україна +38(066)3369027, salamatina@mnau.edu.иa

\title{
Особливості вживання стилістичних засобів різних рівнів в іншомовній публіцистиці
}

Анотація. Стаття присвячена дослідженню основних стилістичних характеристик текстів преси, в тому числі різних лексичних засобів вираження експресивності, а саме фразеологізмів та їх інновацій. Висвітлено теоретичні засади дослідження публічистичного тексту в мовознавстві та визначено, яке експресивно-емочійне забарвлення мають у ньому фразеологізми.

Ключові слова: лексичні засоби, англомовна та німецькомовна преса, фразеологізми, газетно-публіцистичний стиль, стилістичні характеристики.

Abstract. This article is devoted to the study of the basic stylistic characteristics of various texts in the foreign press, including the texts of the interview genre, as well as various lexical means of representation the expressiveness of such texts, taking into account phraseologisms and their innovations. The theoretical principles of study of journalistic texts in linguistics are highlighted and their main stylistic characteristics are displayed. It is determined that press phraseologisms play the great expression-emotional role in the foreign journalistic texts. It is possible to define that stylistic description of phraseological units of the press is based on their expressive charge and expressive properties. It is found out that the selection of stylistic means in modern journalistic texts is also motivated by the features: standard and expression. The requirement to influence the mass reader creates such a specific feature of modern journalistic text as its expressive nature, and the requirement for the speed of information transmission and its socially importance creates such a feature as neutrality or standard. Standardization is manifested in the selection of stylistic means of different levels: lexical, morphological, syntactic, figurative, graphic, 
which are typical for the texts of this type. The expressiveness of the stylistic means makes it possible to convey the emotional, connotative, and evaluative aspect of the events and facts reflected in the press in order to increase the influence on the mass reader.

Keywords: lexical means, English and German-language press, phraseologisms, newspaper journalistic style, stylistic characteristics.

Аннотащия. Статья посвящена исследованию основных стилистических характеристик текстов прессы, в том числе различных лексических средств выражения экспрессивности, а именно фразеологизмов и их инновачий. Освещены теоретические основы исследования публицистического текста в языкознании и определено, какую экспрессивноэмоииональную окраску имеют в нем фразеологизмы.

Ключевые слова: лексические средства, англоязычная $u$ немеикоязычная пресса, фразеологизмы, газетно-публицистический стиль, стилистические характеристики.

Вступ. Розгляд мови як діяльності, що супроводжується ментальними процесами та слугує засобом реалізації інтенцій індивіда, зумовлює актуальність залучення публіцистичних текстів, що сприяють поширенню соціальної інформації на масову й дистантно розташовану аудиторію і мають чітко виражену комунікативну організацію та прагматичний потенціал, до орбіти лінгвістичних досліджень, до розгляду їх структурних і стилістичних відмінностей (Г.П. Апалат [2, с. 100], А.В. Кікало [5, с. 54], В.Ю. Миронова $[8$, c. 9]. Не зважаючи на численні спроби дослідження текстів преси, слід констатувати недостатню увагу науковців до комунікативного та прагматичного аспектів використаних у них стилістичних засобів.

Наприклад, на вибір стилістичних мовних та немовних засобів в публіцистичному жанрі інтерв'ю впливає велика кількість суб'єктивних та об'єктивних чинників. Об'єктивними чинниками вважається комунікативний намір та прагматична настанова журналіста, який завжди виконує в інтерв'ю соціальну роль запитувача важливої інформації, комунікативний намір респондента у разі подання інформації в офіційних та напівофіційних текстах інтерв'ю, загальні особливості (імідж) видання, в якому надруковано текст інтерв'ю, тематичний напрям тексту тощо [1, с. 93]. Суб'єктивними чинниками у виборі мовних засобів виступають передусім індивідуальні риси всіх учасників комунікативної ситуації інтерв'ю.

Матеріал i методи проведення дослідження. Матеріалом дослідження слугують вилучені шляхом суцільного добору 500 текстів англомовної та німецькомовної преси. У дослідженні використано такі методи та прийоми аналізу у комплексному поєднанні: метод лінгвістичного спостереження дав змогу окреслити риси публіцистичного стилю в цілому, визначити особливості стилістичних засобів, вжитих у окремих 
досліджуваних текстах преси, а також надати характеристику складників їх прагматики; метод фразеологічної ідентифікації - для виявлення фразеологічності того чи іншого стійкого словесного комплексу, вжитого у публіцистичному тексті; контекстно-ситуативний та прагмасемантичний методи аналізу мовленнєвих актів сприяли виокремленню мовленнєвих стратегій і тактик авторів текстів преси.

$\begin{array}{rcccr}\text { Виклад } & \text { основного матеріалу та } & \text { обговорення } & \text { результатів } \\ \text { дослідження. } & \text { Актуальність статті } & \text { визначається } & \text { загальною }\end{array}$ антропоцентричною та функціонально-прагматичною орієнтацією на виявлення стилістичних i структурно-семантичих параметрів організації текстів в англомовній та німецькомовній пресі. Попри наявність різноаспектних досліджень окремих особливостей текстів преси в низці лінгвістичних традицій у загальному мовознавстві й дотепер залишається нерозв'язаною проблема комплексного лінгвістичного дослідження іншомовного публіцистичного тексту.

Мета статті - визначити особливості вживання стилістичних засобів різних рівнів в іншомовній публіцистиці на прикладі текстів інтерв'ю англомовної та німецькомовної преси.

Стаття присвячена дослідженню основних стилістичних характеристик різних текстів преси, в тому числі жанра інтерв'ю, а також різних лексичних засобів вираження експресивності таких текстів, враховуючи фразеологізми та їх інновації.

Завдання дослідження - висвітлити теоретичні засади вивчення публіцистичних текстів в мовознавстві та виділити їх основні стилістичні характеристики.

Відомо, що мовна та немовна інформація публіцистичного тексту зорієнтована на соціального адресата. Саме це допомогло визначити його загальну класифікаційну рису - вторинність, належність до відкладеної комунікації, оскільки автор є віддаленим у часі та просторі відносно масового адресата (читача). Виходячи з цього, в публіцистичному тексті автори кодують інформацію засобами, які вони вважають найбільш пристосованими до соціально-типологічних та психолого-особистісних характеристик потенційного соціального адресата текстів - читача [9, с. 123].

Добір стилістичних засобів у сучасних публіцистичних текстах мотивується також властивими їм рисами - стандартом та експресією.

Дослідження вітчизняних та зарубіжних науковців показали, що існує низка функцій, притаманних публіцистиці взагалі: інформативна, просвітницька, популяризаторська, виховна, організаторська, аналітикокритична, гедоністична (розважальна) тощо. Однак основними іiі функціями, що вбирають у себе всі вище перелічені функції та найбільш безпосередньо виражаються у стилістиці мовлення, вчені називають інформативну та прагматичну, або функцію впливу на масового адресата (читача) [14, S. 120]. 
Специфіка інформативної функції, що виконує публіцистичний текст, i яку можна визначити як денотативну, полягає у тому, що, по-перше, інформація у цій сфері суспільної діяльності адресується не вузькому колу спеціалістів, як, наприклад, у сфері науки, а широким масам, усім носіям мови; по-друге, тут необхідна швидкість передачі інформації, що не $\epsilon$ необхідним, наприклад, в офіційно-діловому стилі [16, S. 116].

Інформативна функція текстів преси втілюється у тих особливостях публіцистичного стилю, що пов’язані з виявом інтелектуальності мовлення. Такими стильовими рисами вважаються:

1) підкреслена документально-фактологічна точність викладення;

2) стриманість, деяка офіційність або «нейтральність», що підкреслюють значимість фактів, інформації;

3) певна узагальненість i понятійність викладення як підсумок аналітичності та фактографічності (нерідко разом із образною конкретністю вираження);

4) аргументованість викладеного [4, с. 82] тощо.

Особливий характер має i функція впливу, яку визначають як прагматичну: якщо у науковому стилі автор лише апелює до розуму адресата, аргументує будь-які положення за допомогою логічних доводів або точних розрахунків, то публіцист запевняє шляхом емоційного впливу на читача $\mathrm{i}$ тому в явній формі виражає своє ставлення до повідомлюваного. Дуже важливим $є$ також те, що це ставлення не завжди є суто індивідуальним, воно, зазвичай, $є$ вираженням думки певної соціальної групи, що адресоване масам [6, с. 160]. Наприклад, назва німецькомовного публіцистичного тексту "Nationalpark Eifel - Chance der Region"/ «Національний парк Айфель - шанс регіону» (Live) повністю передає основну думку спільноти щодо доцільності відкриття у регіоні національного парку і приваблення туди туристів.

Отже, вимога здійснення впливу на масового читача створює таку специфічну особливість сучасного публіцистичного тексту, як його експресивний характер, а вимога швидкості передачі інформації, причому суспільно важливої, - таку його рису, як нейтральність або стандарт.

Звісно, що стандарт зумовлює типовість організації публіцистичного тексту на різних рівнях (лексико-граматичному, стилістичному, структурному), а експресивність називають важливим чинником реалізації його прагматичної функції, оскільки експресивні риси є допоміжними у здійсненні комунікативних намірів та прагматичної настанови автора. Реалізація прагматичної мети автора текстів преси спрощується за рахунок максимально вираженої прагматичної функції знаків усіх рівнів, властивої публіцистичним текстам масової комунікації загалом ([13, с. 210].

Стандартизованість виявляється у доборі стилістичних засобів різних рівнів - лексичних, морфологічних, синтаксичних, фігур, графічних, графіко-фонетичних, які $\epsilon$ характерними для текстів цього типу. Експресивність стилістичних засобів дозволяє передати емоційний, 
конотативний, оцінний аспект відображених у текстах преси подій та фактів [11, с. 145].

Під експресивністю публіцистичного тексту розуміють усі застосовані мовні засоби, що дозволяють виразно уявити його зміст та ставлення до нього автора, аби посилити вплив на адресата [7, с. 179]. Дійсно, оскільки тексти преси адресовані широкій аудиторії, автор стоїть перед необхідністю зацікавити читача не лише темою виступу, але і його мовною формою. 3 цим пов'язують різний ступінь експресивного забарвлення мовлення, що включає у себе доволі тонкі оцінні відтінки, які супроводжують мовлення, роблять його виразним. Експресія незмінно супроводжується ускладненнями та розширеннями змістової структури слова і речення [12, с. 12].

Узагальнюючий відносно функціональності та емоційності зміст терміну «експресія» Т.Г. Винокур вважає зручним, оскільки у висловлюванні ці дві ознаки найчастіше виявляються поєднаними одна з одною. На думку лінгвіста, злиття різних за виникненням експресивних елементів, що формують стилістичне значення, - це не уподібнення їх один одному, не втрата ними власних диференційних ознак, а вирівнювання їх функцій на комунікативній лінії узусу, коли і ті, й інші поєднуються для створення виразного ефекту висловлювання - його експресії [3, с. 57].

Розглянемо комунікативно-прагматичні особливості стилістичних засобів різних рівнів, вжитих у текстах іншомовної преси.

Стилістично нейтральні лексичні засоби складають стандартизований словник публіцистичних текстів та виступають денотатом соціально важливих реалій.

Експресивні лексичні засоби створюють позитивний або негативний експресивний ефект. Лексичні засоби преси відносяться переважно до загальновживаної лексики, оскільки публіцистичні тексти розраховані на широке коло читачів, а тому мають бути пристосованими до перцептивних здібностей якомога більшої кількості потенційних адресатів [1, с. 95].

Фразеологізми у пресі дають можливість розв'язати одне із головних завдань цього стилю мови - поєднати максимальний рівень інформативності 3 емоційною наповненістю, експресивністю вислову. Дослідження особливостей функціонування фразеології преси відкриває шлях до вивчення особливостей реалізації оцінних тактик, спрямованих на досягнення основних цілей газетно-публіцистичного стилю, що дає можливість зрозуміти як прагматичні умови, так і прагматичний механізм успішності інформування.

Одним із уживаних у текстах сучасної преси експресивних лексичних засобів є терміни з відповідної теми або предмету. Вживання термінів зазвичай сприяє успішній реалізації інформативного комунікативного наміру та прагматичної настанови автора публіцистичному тексті, оскільки вони знімають необхідність 
перифрастичного тлумачення соціальних реалій та явищ, лаконізують комунікацію за рахунок прямої, експліцитної номінації фактів та феноменів. Вибір термінів зумовлений загальною тематичною спрямованістю тексту, професійною компетенцією автора та його зорієнтованістю на частково підготовленого до сприйняття цього тексту соціального адресата - читача. До речі, медичні терміни у сучасній періодиці часто вживаються метафорично й $\epsilon$ важливим засобом підвищення експресивності текстів різних жанрів преси [15, с. 687].

Історизми, наприклад, є одним із експресивних засобів, властивих текстам англомовної преси. Наведемо приклад з репліки інтерв'ю:

You have said that if you were alive during the Third Reich, you might have found yourself in prison. Why? (Newsweek)

Згадка в поданому уривку інтерв’ю про Третій Рейх сприяє виклику сильних негативних емоцій у читача, чого і вимагає автор.

Ще однією особливістю фразеологічної номінації у пресі $є$ те, що тексти інтерв'ю виконують роль розповсюджувача нової інформації, у тому числі фразеологічних неологізмів. Газети, журнали, Інтернет-видання стають найбільш чутєвими регістраторами нових тенденцій у мові, в тому числі й появи фразеологічних інновацій. Наведемо приклад, фразеологічної інновації 3 мови відомих політиків: Und das ist gut so - пішла від Клауса Воверайта (соціал-демократична партія), бургомістра Берліна, який ужив це висловлювання у своєму першому інтерв'ю (після того, як офіційно оголосив, що він гомосексуаліст): "Und das ist gut so":

"Doch spätestens nach der Wahl wird die nächste Gesundheitsreform kommen. Und das ist auch gut so" (Tagesspiegel).

Перефразування крилатого вислову 3 драми «Гамлет» В. Шекспіра Etwas ist faul im Staate Dänemark, який має іронічне забарвлення зі значенням «тут щось негаразд».

Etwas ist faul in diesem Staat - der auch Dänemark heißen könnte (Die Zeit).

Автори іншомовної преси лаконізують тексти за рахунок абревіатур, вживання яких дозволяє скоротити термінологічні лексичні одиниці та сприяє більшій інформативності текстів. Важливу комунікативну роль у текстах сучасної преси відіграють топоніми, які надають додаткову логодейктичну інформацію і підвищують вірогідність успішної комунікації інформації публіцистичного тексту.

Стилістичними засобами морфологічного рівня $є$ особливості вживання частин мови або їх граматичних категорій 3 метою набуття певного комунікативного або прагматичного ефекту [17, с. 184]. Прикметники та прислівники виступають одним із найуживаніших засобів надання текстам інтерв'ю іншомовної преси експресивності. Часові категорії дійсного способу дієслів вживаються з метою максимального відтворення реального аспекту зображуваної ситуації або події [10, с. 110]. 
Синтактико-стилістичні засоби вживаються у текстах преси з метою успішної комунікації на рівні синтаксичної організації [1, с. 98]. Одним із розповсюджених синтаксичних засобів реалізації іншомовних публіцистичних текстів $\epsilon$ еліптичні речення. Вони дозволяють їх лаконізувати та сприяють підвищенню їх інформативності.

Уживання засобу прямої мови у публіцистичних текстах свідчить про їх вторинність. Пряма мова $є$ типовим синтактико-стилістичним засобом, який підвищує загальну інформативність тексту в пресі та вірогідність комунікованої інформації за рахунок іiі незмінюваності [10, с. 120]. Непряма мова традиційно використовується для створення ефекту інформативно насиченої комунікації.

Висновки. Отже, вибір стилістичних засобів різних рівнів здійснюється авторами текстів в сучасній іншомовній пресі згідно 3 їх комунікативними намірами та прагматичною настановою. Вибір лексичних засобів пов'язаний з реалізацією у публіцистичних текстах стандарту та експресії, а також мовної економії шляхом лаконізації, метафоризації тексту; створення ефекту дейктичного занурення, підвищеної уваги тощо. Як показують здобутки вивчення панорами критики дослідження, ми дійшли висновку, що фразеологізми використовуються у пресі як постійний «робочий» матеріал. Чим більше застосовують фразеологізми у пресі, тим яскравіше матеріал та ефектніше вплив на читача. Морфологічні засоби також надають текстам сучасної іншомовної преси специфічної жанровостилістичної забарвленості. Експресивний синтаксис виявляється у використанні засобів задля створення експресивно насиченого тексту.

\section{ЛІТЕРАТУРА}

1. Адмони В.Г. Отбор языковых средств и вопросы стиля / В.Г. Адмони, Т.И. Сильман // Вопросы языкознания. - 1994. - № 4. - С. 93-100.

2. Апалат Г.П. Структура, семантика і прагматика текстів інтерв'ю (на матеріалі сучасної англомовної преси) : дис. ... канд. філол. наук : 10.02.04 / Апалат Ганна Павлівна. - К., 2002. - 203 с.

3. Винокур Т. Г. Закономерности стилистического использования языковых единиц / Винокур Т. Г. - М.: Наука, 1980. - 237 с.

4. Девкин В. Д. Диалог: немецкая разговорная речь в сопоставлении с русской / Девкин В. Д. - М.: Высшая школа, 2001. - 159 с.

5. Кікало А. В. Комунікативно-прагматичні особливості спортивного тексту французької преси : дис. ... канд. філол. наук : 10.02 .05 / Кікало Анжеліка Василівна. - Ужгород, 1995. - 154 с.

6. Крылова О. А. Лингвистическая стилистика / Крылова О. А. - М. : Высшая школа, 2006. - 319 с. 
7. Маслова В. А. Параметры экспрессивности текста / В. А. Маслова // Человеческий фактор в языке: Языковые механизмы экспрессивности. - Минск: ТетраСистемс, 1991. - С. 179-204.

8. Миронова В. Ю. Лингвистическая характеристика речевого жанра научно-технического реферата (на материале немецких научнотехнических реферативных журналов) : автореф. дисс. на соискание уч. степени канд. филол. наук : спец. 10.02 .04 „Германские языки” / В. Ю. Миронова. - М., 1975. - 20, [1] с.

9. Островська О.М. Лінгвостилістичні засоби оцінки : дис. ... канд. філол. наук : 10.02.04 / Островська Олександра Миколаївна. - Львів, 2001. - 176 с.

10. Почепцов Г.Г. Коммуникативные технологии двадцатого века / Почепцов Г.Г. - М. : “Рефл-бук”, К.: “Ваклер”, 1999. - 352 с.

11. Приходько Г.І. Способи вираження оцінки в сучасній англійській мові / Приходько Г.І. - Запоріжжя : Запорізьк. держ. ун-т. - 2001. - 361 с.

12. Солганик Г.Я. Выразительные ресурсы лексики публицистики / Г.Я. Солганик // Поэтика публицистики. - М., 1990. - С.10-20.

13. Чабаненко В. А. Стилістика експресивних засобів української мови / Чабаненко В. А. - Запоріжжя : ЗДУ, 2002. - 351 с.

14. Fleischer W. Stilistik der Deutschen Gegenwartssprache / Fleischer W., Michel G., Starke G. - Frankfurt am Main; Berlin; Bern : Peter Lang, 1996. - 341 S.

15. Kronrod A. Accessibility theory and referring expressions in newspaper headlines / A. Kronrod, O. Engel // Journal of Pragmatics. - 2001. - Vol. 33, № 5. - P. 683-699.

16. Seidler H. Allgemeine Stilistik / Seidler H. - Göttingen : Vandenhoeck \& Ruprecht, 2003. - 359 S.

17. Turner G. W. Stylistics - Harmondsworth / Turner G. W. - H.: Penguin books LTD, 1975. - $256 \mathrm{p}$. 